\title{
Response to Fertilization of Different Tree Species in the Urban Environment
}

\author{
F. Ferrini and M. Baietto
}

\begin{abstract}
The influence of fertilization on shoot growth, leaf gas exchange, leaf chlorophyll content, and mineral content was monitored on sweetgum (Liquidambar stryraciflua L.), Japanese pagoda tree (Styphnolobium japonicum Schott), and European ash (Fraxinus excelsior L.) over a 3-year period after planting in the urban environment. The research was carried out on newly planted trees that were placed in different urban sites and fertilized after planting. Fertilization was repeated for 2 years after planting at the beginning of the spring. There were contrasting results according to the species and the year of measurements. Fertilization was to a limited extent effective in the first year after planting but failed to provide better results in the following years. Thus, the results of this research do not support the utility of fertilizer application as a method to improve plant establishment, growth, or physiology after transplanting in the urban environment.

Key Words. Fraxinus excelsior; leaf gas exchanges; leaf mineral content; Liquidambar styraciflua; plant nutrients; plant physiology; Styphnolobium japonicum.
\end{abstract}

The supply of nutrients to trees planted in the urban environment in the form of artificial fertilizers is a subject on which there are different opinions (Miller, 1998, 2003; Marion 2003). Experimental evidence and practical experience show that the different results can be related to the mechanical and physical condition of the soil, the climate, and the quality of plant material and its age (Gilman et al. 2000; Smiley et al. 2002; Sharenbroch and Lloyd 2004). In addition, the fertilizer type and the placement of the fertilizer may affect plant response (van de Werken 1984; Gilman 1987). Hence, a wide variation in the practical results of fertilizing trees in the urban landscape is to be expected, especially in the relative length of time that is necessary to produce comparable results. In fact, particularly young trees may not, or often do not, promptly respond to applications of nitrogen or other elements (Gilman et al. 2000). As recently reported by Sharenbroch and Lloyd (2004), because of the limited research on urban plants, fertilization recommendations from nonurban systems have been adapted for use in urban areas.

As regards the influence on plant growth, Whitcomb (1979) found that application of fertilizers did not enhance the posttransplant growth of several landscape trees. Current tree-care recommendations suggest limiting fertilization during the establishment period (Marion 2003; Siewert et al. 2003). Growth in the first year can also be affected by internal reserves of nutrients and photosynthates. As a result, a plant that has been well fertilized in the nursery and has a large root system is likely to better tolerate poor growing conditions in the first year after planting. However, such plants may show less response to nutrient addition than plants with a low nutrient content, particularly in the early part of their first growing season (Bradshaw et al. 1995).

On the other hand, some studies in the literature indicate that the application of inorganic fertilizers aids plant establishment and that it is an acceptable method of improving tree health and vigor (Rao et al. 2003; Smith 2003). Schulte and Whitcomb (1975) found that nitrogen fertilization at planting positively affected growth in the first year after planting. More recently, results obtained by Ferrini et al. (2005) on English oak (Quercus robur L.) indicate that shoot growth, leaf area, chlorophyll content, and leaf gas exchange were higher in fertilized plants, especially during the second and third years after planting.

As to the time of fertilization, research shows that in general the time of maximum nutrient uptake is from budbreak in spring to leaf color change in fall (Smiley et al. 2002), and the differences can be due to the different climate conditions. However, some authors state that early spring and late fall are not the best time to fertilize trees (Struve 2002); others recommend fertilizing in early spring or late fall, despite low nitrogen uptake potential during those seasons (Rose 1999). Late nitrogen fertilization may decrease winter hardiness, sometimes exhibited by trees fertilized in the fall, although on this topic some contrasting results can be found in the literature (Smiley and Shirazi 2003).

All of this means that in case of doubt, the only definite answer can be obtained by local tests, because a precise knowledge of how trees respond to changes in tree fertility is critical to the effective use of fertilizers in the landscape (Hagen 2000). Thus, there is a need to perform experiments 
Table 1. Effect of fertilization on net photosynthesis (Pn), evaporation rate (E), on water use efficiency (WUE) and on

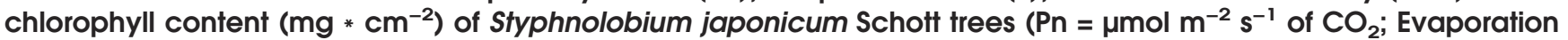
rate $=\mathrm{mmol} \mathrm{m} \mathrm{m}^{-2} \mathrm{~s}^{-1}$ of $\mathrm{H}_{2} \mathrm{O}$; WUE = Pn/Evaporation rate). Data on leaf gas exchange are the average of three sampling dates in the first and in the second year and five in the third year.

\begin{tabular}{|c|c|c|c|c|c|c|c|c|}
\hline \multirow[b]{2}{*}{ Treatment } & \multicolumn{4}{|c|}{2003} & \multicolumn{4}{|c|}{2004} \\
\hline & Pn & $\mathrm{E}$ & WUE & Chlor. & Pn & $\mathrm{E}$ & WUE & Chlor. \\
\hline Control & $11.22 \mathrm{~b}^{*}$ & $2.44 \mathrm{~b}$ & $4.60 \mathrm{a}$ & $15.98 \mathrm{a}$ & $9.86 \mathrm{a}$ & $3.13 \mathrm{a}$ & $3.15 \mathrm{a}$ & $14.33 \mathrm{a}$ \\
\hline Fertilization & $14.03 \mathrm{a}$ & $3.05 \mathrm{a}$ & $4.60 \mathrm{a}$ & $16.67 \mathrm{a}$ & $8.25 \mathrm{~b}$ & $2.55 \mathrm{~b}$ & $3.24 \mathrm{a}$ & $15.20 \mathrm{a}$ \\
\hline
\end{tabular}

*Values differ significantly when followed by different letters at $P \leq 0.05$ (LSD test).

under different soil and climate conditions. The following study was therefore undertaken to determine the influence of fertilization on three typical tree species in the urban environment.

\section{MATERIALS AND METHODS}

Two experiments were initiated in spring 2002 in two different urban sites, one in a new parking lot situated in the S-W part of Milan, Italy, and the other in a downtown street. The soil tests results of three samples per each location (obtained by mixing five subsamples per each sample) taken prior to treatment application and establishment of the planting showed silty-loamy soils with a subalkaline $\mathrm{pH}$ for both locations, with a balanced composition in terms of nutrient content except for nitrogen, which was around $0.6 \mathrm{~g} / \mathrm{kg}(0.2$ $\mathrm{oz} / 1.32 \mathrm{lb})$ in the parking lot and $0.45 \mathrm{~g} / \mathrm{kg}(0.2 \mathrm{oz} / 1 \mathrm{lb})$ in the street.

\section{Experiment 1}

In spring 2002, 14 common ash (Fraxinus excelsior L.) trees, 5 years old, 4 to $4.5 \mathrm{~m}$ (13.2 to $14.9 \mathrm{ft})$ tall, 14 to $18 \mathrm{~cm}(5.6$ to $7.2 \mathrm{in}$ ) in circumference (measured at $1.3 \mathrm{~m}$ height [ $4.3 \mathrm{ft}]$ ) and 10 Japanese pagoda trees (Styphnolobium japonicum Schott, formerly known as Sophora japonica L.), 5 years old, 4 to $4.5 \mathrm{~m}$ (13.2 to $14.9 \mathrm{ft})$ tall, 14 to $18 \mathrm{~cm}$ (5.6 to $7.2 \mathrm{in})$ in circumference (measured at $1.3 \mathrm{~m}$ height $[4.3 \mathrm{ft}]$ ) were planted in parking-lot islands in a new public parking lot. All trees were obtained from the same nursery and planted at the same time. Japanese pagoda tree is one of the few commercially important, temperate, woody members of the Papilionoideae family that do not nodulate, though recent research has shown that this species also has putative early noduling (Foster et al. 2000). Planting holes were 1.5 times the width and the same depth of the root ball (size of the root ball was 40 to $45 \mathrm{~cm}$ [16 to $18 \mathrm{in}$ ] in diameter). Trees were placed in the holes and backfilled with excavated soil and were planted in a completely randomized block design. Trees were watered and some soil was added to compensate for settling. Trees of all treatments were regularly irrigated in the first year after transplanting, then only when needed during the springsummer period.
Before budbreak, seven subjects of Fraxinus and five of Styphonolobium were fertilized with $1 \mathrm{~kg}$ (2.2 lb) of 15-9-15 (commercial product Nitrophoska ${ }^{\circledR}$ Gold $^{\circledR}-$ BASF with $2.5 \%$ nitric nitrogen, $7.5 \%$ ammoniacal nitrogen, $5 \%$ slow-release nitrogen [ISODUR], $9 \% \mathrm{P}_{2} \mathrm{O}_{5}, 15 \% \mathrm{~K}_{2} \mathrm{O}$ ) fertilizer granules were distributed over the soil surface (approx. $2.5 \mathrm{~m}^{2}\left[27 \mathrm{ft}^{2}\right]$ ) around the planting hole by superficial hand-tilling $(<10 \mathrm{~cm}$ [4 in], with no real damage to roots) with a hoe and mixing with the soil. The amount chosen was higher than those generally recommended for urban tree fertilization (10 to $40 \mathrm{~g} / \mathrm{m}^{2}$ [0.35 to $1.4 \mathrm{oz} / 108$ to $432 \mathrm{ft}^{2}$ ] of nitrogen) (Bradshaw et al. 1995; Rose 1999; Struve 2002) because soil chemical analysis before the beginning of the experiment indicated low soil $N$ values at both locations.

Seven ashes and five Japanese pagoda trees were handtilled at the same time and used as control. The second and the third year after transplanting, all the treatments were repeated: the same amount of fertilizer was applied immediately before budbreak by superficial hand-tilling, and control plants were hand-tilled at the same time. Trees were grown in a lawn situation with no clipping removal and the turf was not allowed to grow close to the trunk.

\section{Experiment 2}

In spring 2002, 30 sweetgum trees (Liquidambar styraciflua L.), 6 years old, 5 to $6 \mathrm{~m}$ ( 16.5 to $19.8 \mathrm{ft})$ tall, 14 to $18 \mathrm{~cm}(5.6$ to $7.2 \mathrm{in}$ ) in circumference (measured at $1.3 \mathrm{~m}$ height $[4.3 \mathrm{ft}]$ ) were planted along a busy lane where trees are subjected to a rather high stress level (mainly from air pollution and soil compaction). All trees with identical size characteristics were obtained from the same nursery.

Planting holes were 1.5 times the width and the same depth of the root ball (size of the root ball was around $50 \mathrm{~cm}$ [20 in] in diameter). Trees were placed in the holes and backfilled with excavated soil and were treated in a completely randomized block design. Trees of all treatments were watered and some soil was added to compensate for settling. Trees of all treatments were irrigated twice a week during spring and summer.

Before budbreak (early April), ten subjects were fertilized with the same product and using the same technique as described in experiment 1 ; ten trees received a second fertiliza- 
Table 2. Effect of fertilization on net photosynthesis (Pn), evaporation rate (E), on water use efficiency (WUE) and on chlorophyll content $\left(\mathrm{mg} * \mathrm{~cm}^{-2}\right)$ of Fraxinus excelsior $\mathrm{L}$. trees $\left(\mathrm{Pn}=\mu \mathrm{mol} \mathrm{m} \mathrm{m}^{-2} \mathrm{~s}^{-1}\right.$ of $\mathrm{CO}_{2}$; Evaporation rate $=\mathrm{mmol}$ $\mathrm{m}^{-2} \mathrm{~s}^{-1}$ of $\mathrm{H}_{2} \mathrm{O}$; WUE = Pn/Evaporation rate). Data on leaf gas exchange are the average of three sampling dates in the first and in the second year and five in the third year.

\begin{tabular}{|c|c|c|c|c|c|c|c|c|}
\hline \multirow[b]{2}{*}{ Treatment } & \multicolumn{4}{|c|}{2003} & \multicolumn{4}{|c|}{2004} \\
\hline & Pn & E & WUE & Chlor. & Pn & E & WUE & Chlor. \\
\hline Control & $12.43 \mathrm{a}^{*}$ & $2.76 \mathrm{a}$ & $4.50 \mathrm{a}$ & $19.01 \mathrm{a}$ & $4.38 \mathrm{a}$ & $1.34 \mathrm{a}$ & $3.27 \mathrm{a}$ & $14.97 \mathrm{a}$ \\
\hline Fertilization & $13.54 \mathrm{a}$ & $2.92 \mathrm{a}$ & $4.64 \mathrm{a}$ & $20.88 \mathrm{~ns}$ & $4.13 \mathrm{a}$ & $1.26 \mathrm{a}$ & $3.28 \mathrm{a}$ & $15.70 \mathrm{a}$ \\
\hline
\end{tabular}

*Values differ significantly when followed by different letters at $P \leq 0.05$ (LSD test).

tion $(0.5 \mathrm{~kg}[1.1 \mathrm{lb}])$ treatment at the end of June; and ten additional trees were left as control, with no fertilizer addition. All plants were hand-tilled at the same time. The second and the third year after transplanting, all the treatments were repeated: the same amount of fertilizer was applied immediately before budbreak and for the refertilized trees also at the end of June, by superficial hand-tilling; all the other plants were hand-tilled at the same time. The planting area around the trees was bare because of the high compaction due to cars being parked close to the plants.

\section{Data Collection}

The following data were collected in both experiments. Instantaneous net photosynthesis $(\mathrm{Pn})$, transpiration rate $(\mathrm{E})$, and water use efficiency (WUE, calculated by dividing Pn by E) were measured three times in 2002 (only on sweetgum, since the leaves of the other two species the first year were too small to be inserted in the cuvette), three times in 2003 (once in June, once in July, and once at the end of August), and five times in 2004 (from the beginning of June to the end of August) using the CIRAS-1 portable infrared gas analyzer (PP Systems, Hertfordshire, U.K.) in 2002 and 2003 and the CIRAS-2 (PP Systems, Hertfordshire) in 2004. Measurements of leaf gas exchange were started in mid-June according to some reports in the literature that indicate that the development of full photosynthetic capacity took approximately 50 to 70 days after budbreak in different years (Morecroft et al. 2003). The readings were taken between 8 A.M. and 2 P.M. in sunny days on five fully expanded leaves per plant on six (five on Japanese pagoda tree) plants per treatment; the leaves were chosen from the outer part of the crown and at different heights, under conditions of natural light

Table 3. Effect of fertilization on leaf mineral content (\%) of Styphnolobium japonicum Schott trees.

\begin{tabular}{llllllll}
\hline & \multicolumn{3}{c}{2003} & & \multicolumn{3}{c}{2004} \\
\cline { 2 - 4 } \cline { 6 - 8 } Treatment & $\mathrm{N}$ & $\mathrm{P}$ & $\mathrm{K}$ & & $\mathrm{N}$ & $\mathrm{P}$ & $\mathrm{K}$ \\
\hline Control & $2.48 \mathrm{a}^{*}$ & $0.33 \mathrm{a}$ & $1.41 \mathrm{a}$ & & $2.70 \mathrm{a}$ & $0.09 \mathrm{a}$ & $0.87 \mathrm{a}$ \\
Fertilization & $2.56 \mathrm{a}$ & $0.24 \mathrm{a}$ & $1.34 \mathrm{a}$ & & $2.54 \mathrm{a}$ & $0.09 \mathrm{a}$ & $1.26 \mathrm{a}$ \\
\hline
\end{tabular}

*Values differ significantly when followed by different letters at $P \leq 0.05$ (LSD test). saturation (PAR $>1,000 \mu \mathrm{mol} * \mathrm{~m}^{-2} * \mathrm{~s}^{-1}$ ). Chlorophyll content was determined in September (only in 2003 and 2004 for Fraxinus and Styphnolobium) on the same leaves with a portable chlorophyll meter (SPAD-502 Minolta Corp., Ramsey, NJ, U.S.). Previous calibration curves were established per each species by measuring absorbance at 664,647 , and $625 \mathrm{~nm}$ with a Hitachi U-2000 spectrophotometer after extraction with dimethylformamide (DMF) (Moran 1982). Triplicate readings were taken around a midpoint near the mid-rib of each leaf sample and the values averaged.

Shoot elongation was determined on 20 shoots per plant at the end of the growing season. At the same time fresh and dry weight (after drying process in an $80^{\circ} \mathrm{C}\left[176^{\circ} \mathrm{F}\right]$ heater until constant weight) were determined on ten leaves per plant on six plants per treatment (only in 2003 and 2004 for Fraxinus and Styphnolobium). The leaves were chosen from the outer part of the crown at different heights, with similar conditions of shape and weight. The same leaves were evaluated for mineral content; this analysis was carried out by a specialized laboratory (Minoprio Analisi e Certificazioni, Como, Italy). All the data regarding plants were analyzed using the oneway analysis of variance (ANOVA) using SPSS (Release 11.5 for Windows). Treatment means were separated by protected LSD, with $P \leq 0.05$ level of significance.

\section{RESULTS AND DISCUSSION}

\section{Experiment 1}

\section{Gas Exchange}

Considering the average of the different sampling dates, differences were found for net photosynthesis (Pn) and transpi-

Table 4. Effect of fertilization on leaf mineral content (\%) of Fraxinus excelsior L. trees.

\begin{tabular}{llllllll}
\hline & \multicolumn{3}{c}{2003} & & \multicolumn{3}{c}{2004} \\
\cline { 2 - 4 } \cline { 6 - 7 } Treatment & $\mathrm{N}$ & $\mathrm{P}$ & $\mathrm{K}$ & & $\mathrm{N}$ & $\mathrm{P}$ & $\mathrm{K}$ \\
\hline Control & $2.32 \mathrm{a}^{*}$ & $0.15 \mathrm{a}$ & $0.39 \mathrm{a}$ & & $2.10 \mathrm{~b}$ & $0.15 \mathrm{a}$ & $0.44 \mathrm{a}$ \\
Fertilization & $2.39 \mathrm{a}$ & $0.13 \mathrm{a}$ & $0.57 \mathrm{a}$ & & $2.47 \mathrm{a}$ & $0.07 \mathrm{a}$ & $0.51 \mathrm{a}$ \\
\hline
\end{tabular}

*Values differ significantly when followed by different letters at $P \leq 0.05$ (LSD test). 
Table 5. Effect of fertilization on net photosynthesis (Pn), evaporation rate (E), on water use efficiency (WUE) of Liquidambar styraciflua $\mathrm{L}$. trees $\left(\mathrm{Pn}=\mu \mathrm{mol} \mathrm{m} \mathrm{m}^{-2} \mathrm{~s}^{-1}\right.$ of $\mathrm{CO}_{2}$; Evaporation rate $=\mathrm{mmol} \mathrm{m}^{-2} \mathrm{~s}^{-1}$ of $\mathrm{H}_{2} \mathrm{O}$; WUE $=\mathrm{Pn} /$ Evaporation rate). Data are the average of three sampling dates in the first and in the second year and five in the third year.

\begin{tabular}{|c|c|c|c|c|c|c|c|c|c|}
\hline \multirow[b]{2}{*}{ Treatment } & \multicolumn{3}{|c|}{2002} & \multicolumn{3}{|c|}{2003} & \multicolumn{3}{|c|}{2004} \\
\hline & Pn & $\mathrm{E}$ & WUE & Pn & $\mathrm{E}$ & WUE & Pn & $\mathrm{E}$ & WUE \\
\hline Control & $5.8 \mathrm{c}^{*}$ & $1.26 \mathrm{~b}$ & $4.60 \mathrm{~b}$ & $4.93 \mathrm{a}$ & $1.95 \mathrm{a}$ & $2.53 \mathrm{~b}$ & $7.49 \mathrm{a}$ & $3.07 \mathrm{a}$ & $2.44 \mathrm{a}$ \\
\hline 1 Fertilization & $7.19 \mathrm{~b}$ & $1.37 \mathrm{~b}$ & $5.25 \mathrm{a}$ & $5.50 \mathrm{a}$ & $1.94 \mathrm{a}$ & $2.84 \mathrm{a}$ & $5.97 \mathrm{~b}$ & $2.61 \mathrm{~b}$ & $2.29 \mathrm{a}$ \\
\hline 2 Fertilization & $10.52 \mathrm{a}$ & $1.98 \mathrm{a}$ & $5.31 \mathrm{a}$ & $5.53 \mathrm{a}$ & $2.12 \mathrm{a}$ & $2.68 \mathrm{a}$ & $4.79 \mathrm{c}$ & $2.22 \mathrm{c}$ & $2.16 \mathrm{a}$ \\
\hline
\end{tabular}

*Values differ significantly when followed by different letters at $P \leq 0.05$ (LSD test).

ration (E), while WUE was not affected (Table 1) in both years in the Japanese pagoda tree. In the European ash no significant effects were found in any of the parameters considered following fertilization treatment (Table 2). This is not consistent with what was found by Brix and Mitchell (1986), who reported that nitrogen fertilization increased WUE, presumably by stimulating root growth in Douglas-fir. However, it is difficult to draw conclusions because net photosynthesis was highest in the fertilized trees the first year of measurements, whereas the results were the opposite in the following year, contrary to what was observed in a similar study with oak trees (Ferrini et al. 2005). In 2004, because of the reduction in the irrigation volume, leaf gas exchange was lower compared to the first year. This confirms that water is the most important factor for the trees in the establishment phase.

\section{Chlorophyll Content}

No significant trend emerged from the analysis of total chlorophyll content in both years and in both species (Tables 1 and 2). This is not consistent with other research (Ferrini et al. 2005) that showed a higher chlorophyll content per unit weight in fertilized plants compared to control ones.

\section{Plant Growth}

No significant differences were found between the fertilized trees and the control ones regarding shoot growth and leaf dry weight in both years (data not shown), thus confirming findings by other authors who did not find an appreciable increase in plant growth from fertilizer applications on trees after transplanting (Perry and Hickman 1998; Gilman et al., 2000; Struve 2002).

\section{Leaf Mineral Content}

The foliar nitrogen level did not increase consistently in trees receiving soil-applied fertilizer in both species (Tables 3 and 4) in 2003, whereas a higher foliar nitrogen content was found in Fraxinus in 2004. Similarly, no statistically significant increments in phosphorus and potassium levels were detected in the different years and species. This partly agrees with Perry and Hickman (1998), who observed that fertilization did not affect leaf mineral content and tree growth. In conclusion, no correlation was found between leaf mineral content and growth parameters in this study.

\section{Experiment 2}

\section{Gas Exchange}

In the first season after planting, instantaneous net photosynthesis $(\mathrm{Pn})$ was higher in the trees that were fertilized twice. Differences were also found between the plants fertilized only once and the control trees (Table 5), showing a marked effect of fertilization on this parameter. Trees that received a second fertilization also showed a higher evaporation rate (E) and WUE, but only when compared to control trees.

In the second year, only WUE was higher in the fertilized plants, regardless of the quantity of fertilizer. In the third year, opposite results were obtained: Pn and $\mathrm{E}$ were higher in the control trees, and a statistical difference was also found between the two levels of fertilization. Trees fertilized only once showed a higher level of leaf gas exchange compared to those fertilized twice. No differences in WUE were observed.

It seems reasonable to hypothesize that sweetgum trees responded to fertilization in the first year, but the addition of fertilizer failed to produce any response in the following years. The dry climate of 2003 and 2004 might have prevented nutrient uptake and utilization, especially on these plants, which grow in a disturbed and compacted soil. Tomlinson (1993), in a work carried out on oak species, postulated that increased temperature and reduced rainfall led to nutrient deficiency, fine root mortality, and, eventually, crown dieback as nutrient cations were leached from the soil by acids formed from mineralization and nitrification in excess of tree needs. Although the research by Tomlinson (1993) was conducted in forest stands, the high concentrations of nitrates may have triggered a decline process in our plants as well,

Table 6. Effect of fertilization on chlorophyll content $\left(\mathrm{mg} * \mathrm{~cm}^{-2}\right)$ of Liquidambar styraciflua L. trees.

\begin{tabular}{llll}
\hline Treatment & 2002 & 2003 & 2004 \\
\hline Control & $19.40 \mathrm{~b}^{*}$ & $18.18 \mathrm{~b}$ & $17.56 \mathrm{a}$ \\
1 Fertilization & $20.44 \mathrm{a}$ & $19.09 \mathrm{a}$ & $17.66 \mathrm{a}$ \\
2 Fertilization & $20.65 \mathrm{a}$ & $19.81 \mathrm{a}$ & $17.94 \mathrm{a}$ \\
\hline
\end{tabular}

*Values differ significantly when followed by different letters at $P \leq 0.05$ (LSD test). 
Table 7. Effect of fertilization on leaf mineral content (\%) of Liquidambar styraciflua L. trees.

\begin{tabular}{|c|c|c|c|c|c|c|c|c|c|}
\hline \multirow[b]{2}{*}{ Treatment } & \multicolumn{3}{|c|}{2002} & \multicolumn{3}{|c|}{2003} & \multicolumn{3}{|c|}{2004} \\
\hline & $\mathrm{N}$ & $\mathrm{P}$ & $\mathrm{K}$ & $\mathrm{N}$ & $\mathrm{P}$ & $\mathrm{K}$ & $\mathrm{N}$ & $\mathrm{P}$ & K \\
\hline Control & $2.95 \mathrm{a}^{*}$ & $0.12 \mathrm{a}$ & $0.48 \mathrm{a}$ & $2.22 \mathrm{a}$ & $0.06 \mathrm{a}$ & $0.57 \mathrm{a}$ & $2.21 \mathrm{~b}$ & $0.07 \mathrm{a}$ & $0.25 \mathrm{~b}$ \\
\hline 1 Fertilization & $3.15 \mathrm{a}$ & $0.14 \mathrm{a}$ & $0.81 \mathrm{a}$ & $2.24 \mathrm{a}$ & $0.13 \mathrm{a}$ & $0.82 \mathrm{a}$ & $2.61 \mathrm{a}$ & $0.07 \mathrm{a}$ & $0.57 \mathrm{a}$ \\
\hline 2 Fertilization & $3.06 \mathrm{a}$ & $0.11 \mathrm{a}$ & $0.60 \mathrm{a}$ & $2.37 \mathrm{a}$ & $0.16 \mathrm{a}$ & $0.59 \mathrm{a}$ & $2.49 \mathrm{a}$ & $0.08 \mathrm{a}$ & $0.58 \mathrm{a}$ \\
\hline
\end{tabular}

*Values differ significantly when followed by different letters at $P \leq 0.05$ (LSD test).

which showed a significant reduction of leaf gas exchanges in the third year after planting.

\section{Chlorophyll Content}

Control plants had less total chlorophyll than the fertilized ones in the first 2 years after planting, while in the third year no differences were found among the different treatments (Table 6).

\section{Leaf Mineral Content}

No significant effect of fertilization on leaf mineral content as a percentage of dry weight was found in the first 2 years, but in the third year fertilized trees showed a higher nitrogen and potassium content (Table 7).

\section{Plant Growth}

No effects on shoot growth and leaf dry weight were observed in the first 2 years, but in 2004 shoots were significantly longer in the control trees (data not shown).

Since fertilization led to neither an increase in the leaf content or an increase in shoot growth, it seems that the plants have not taken up different amounts of fertilizer. This might be due to the fact that transplanting often leads to a measurable, long-term water stress that cannot be easily relieved even using fertilization and watering in combination. In addition, trees from the nursery have a decreased root system that can be less capable of acquiring nutrients, leading to no effect on growth and leaf concentrations even with increased fertilization.

\section{CONCLUSIONS}

During the 3-year experiments, the application of fertilizer showed contrasting effects on tree growth and leaf gas exchange. Although we found some differences, they were limited to 1 year, and only to some parameters. Contrary to findings in a previous paper on oak fertilization (Ferrini et al. 2005) the results of this research do not support the utility of fertilizer application as a method to improve plant establishment, growth, and physiology after transplanting in the urban environment. This may be due to the different conditions in which the experiments were conducted: oak trees were studied in an urban park; and ash, Japanese pagoda, and sweetgum trees were studied in a crowded street and in a parking lot. However, research carried out on Ilex rotunda showed that the photosynthetic rate of the trees was higher in urban areas than in suburban areas (Takagi and Gyokusen 2004). Carrying out experiments in the urban environment is often demanding because the variations between neighboring areas may be considerable. Therefore, there are probably other reasons why fertilization may not have affected tree growth and physiology (e.g., climate conditions, changes in soil physical conditions after planting, the presence or absence of maintained turfgrass), so it is difficult to make specific recommendations about tree fertilization in urban sites. Urban forest managers should be aware of this before deciding whether fertilization is appropriate or cost-effective after planting trees in urban stands.

Acknowledgments. Support for this project came in part from the Regione Toscana (Italy) as part of the research project "Research on Multipurpose Green Areas" (RISVEM). A special thanks to the Parks and Gardens Service of Milano Town Council for the technical support to the research.

\section{LITERATURE CITED}

Bradshaw, A., B. Hunt, and T. Walmsley. 1995. The need for nutrients, pp. 157-169. Trees in the urban landscape. E.\&F.N. Spon, London.

Brix, H., and A.K. Mitchell. 1986. Thinning and nitrogen fertilization effects on soil and tree water stress in a Douglas-fir. Canadian Journal of Forest Research 16: 1334-1338.

Ferrini, F., A. Giuntoli, F.P. Nicese, S. Pellegrini, and N. Vignozzi. 2005. Effect of fertilization and backfill amendments on soil characteristics, growth and leaf gas exchanges of English oak (Quercus robur L.). Journal of Arboriculture 31(4):182-190.

Foster, C.M., H.T. Horner, and W.R. Graves. 2000. Accumulation of ENOD2-like transcripts in non-nodulating woody papilionoid legumes. Plant Physiology 124: 741-750.

Gilman, E.F. 1987. Response of hibiscus to soil-applied nitrogen. Proceedings of the Florida State Horticultural Society 100:356-357.

Gilman, E.F., T.H. Yeager, and D. Kent. 2000. Fertilizer rate and type impacts magnolia and oak growth in sandy landscape soil. Journal of Arboriculture 26(3):177-182. 
Hagen, B.W. 2000. Back to basics: tree fertilization. Arborist News 6:34-42.

Marion, D.F. 2003. Tree fertilization in the 21st century: Where to from here?, pp. 3-5. Tree and Shrub Fertilization. Siewert, A., Rao, B., and Marion, D., Eds. Dixon Graphics Publishing, Champaign, IL.

Miller, R.W. 1998. Tree fertilization: science, myth and ethics. Arborist News 6:25-27.

- 2003. Practical application: are we asking the right question and looking in the right places?, pp. 15-20. Tree and Shrub Fertilization. Siewert, A., Rao, B., and Marion, D., Eds. Dixon Graphics Publishing, Champaign, IL.

Moran, R. 1982. Formulae for determination of chlorophyllous pigments extracted with N,N-dimethylformamide. Plant Physiology 69:1376-1381.

Morecroft, M.D., V.J. Stokes, and J.I.L. Morison. 2003. Seasonal changes in the photosynthetic capacity of canopy oak (Quercus robur) leaves: the impact of slow development on annual carbon uptake. International Journal of Biometeorology 47:221-226.

Perry, E., and G.W. Hickman. 1998. Correlating foliar nitrogen levels with growth in two landscape tree species. Journal of Arboriculture 24(3):149-153.

Rao, B., B. Jeffers, and L. Burkhart. 2003. The effect of fertilization and mycorrhizae on newly planted red oaks and sugar maples, pp. 105-111. Tree and Shrub Fertilization. Siewert, A., Rao, B., and Marion, D., Eds. Dixon Graphics Publishing, Champaign, IL.

Rose, M.A. 1999. Nutrient use patterns in woody perennials: implications for increasing fertilizer efficiency in fieldgrown and landscape ornamentals. HortTechnology 9: 613-617.

Sharenbroch, B.C., and J.E. Lloyd. 2004. A literature review of nitrogen availability indices for use in urban landscapes. Journal of Arboriculture 30(4):214-229.

Schulte, S.R., and C.E. Whitcomb. 1975. Effect of soil amendments and fertilizer levels on the establishment of silver maple. Journal of Arboriculture 1:192-195.

Siewert, A., B. Rao, and D.F. Marion. 2003. Tree and Shrub Fertilization. Siewert, A., Rao, B, and Marion, D., Eds. Dixon Graphics Publishing, Champaign, IL.

Smiley, E.T., and A.M. Shirazi. 2003. Fall fertilization and winter hardiness, pp. 93-103. Tree and Shrub Fertilization. Siewert, A., Rao, B, and Marion, D., Eds. Dixon Graphics Publishing, Champaign, IL.

Smiley, T., S. Lilly, and P. Kelsey. 2002. Fertilizing trees and shrubs. Determining if, when, and what to use. Arborist News 2:17-21.

Smith, E. 2003. Tree growth as influenced by fertilizer treatment, pp. 79-81. Tree and Shrub Fertilization. Siewert, A., Rao, B., and Marion, D., Eds. Dixon Graphics Publishing, Champaign, IL.
Struve, D.K. 2002. A review of shade tree fertilization research in the United States. Journal of Arboriculture 28(6):252-263.

Takagi, M., and K. Gyokusen. 2004. Light and atmospheric pollution affect photosynthesis of street trees in urban environments. Urban Forestry Urban Greenery 2: 167-171.

Tomlinson, G.H. 1993. A possible mechanism relating increase soil temperature to forest decline. Water, Air, and Soil Pollution 66:365-380.

van de Werken, H. 1984. Fertilization and other factors enhancing the growth of young shade trees. Journal of Environmental Horticulture 2:64-69.

Whitcomb, C.E. 1979. Factors affecting the establishment of urban trees. Journal of Arboriculture 5(10):217-219.

F. Ferrini (corresponding author)

Full Professor of Urban Arboriculture and Parks and Gardens

Dipartimento di Ortoflorofrutticoltura

University of Florence

Viale delle Idee, 30-50019, Sesto Fiorentino (Florence), Italy

francesco.ferrini@unifi.it

\section{Baietto}

Ph.D. Student

Dipartimento di Produzione Vegetale

University of Milan

Via Celoria, 2-20133, Milano, Italy

Résumé. L'influence de la fertilisation sur la croissance des pousses, les échanges gazeux foliaires, la chlorophylle foliaire et le contenu en minéraux a été mesurée chez le copalme d'Amérique (Liquidambar styraciflua L.), l'arbre à pagode du Japon (Styphnolobium japonicum Schott) et le frêne européen (Fraxinus excelsior L.), et ce sur une période de trois années suivant leur plantation dans un environnement urbain. La recherche a été menée sur des arbres nouvellement plantés qui ont placés dans différents sites urbains et qui ont été fertilisés après leur plantation. La fertilisation a été répétée durant deux années après la plantation, et ce en début de printemps. Les résultats se sont avérés contrastés selon les espèces et l'année où les mesures étaient prises. La fertilisation s'est avérée jusqu'à un certain point effective durant la première année suivant la plantation, mais s'est avérée par la suite être un échec quant à donner de meilleurs résultats lors des années subséquentes. De ce fait, les résultats de cette recherche n'appuient pas l'intérêt d'appliquer des fertilisants comme méthode pour améliorer la reprise des arbres, leur croissance ou leur physiologie après leur transplantation en milieu urbain.

Zusammenfassung. Der Einfluss von Dünger auf das Triebwachstum, Gasaustausch, Blattchlorophyll und Mineralstoffgehalt wurde in einer 3 jährigen Periode nach der Pflanzung im Stadtgebiet 
bei (Liquidambar stryraciflua L.), (Styphnolobium japonicum Schott) und (Fraxinus excelsior L.) untersucht. Die Forschung wurde an neugepflanzten Bäumen, die an unterschiedlichen Standorten platziert und gedüngt wurden, ausgeführt. Die Düngung wurde jeweils im Frühjahr für 2 Jahre nach der Pflanzung wiederholt. Die Ergebnisse waren kontrastreich entsprechend der Baumart und dem Jahr der Messungen. Die Düngung war zu einem begrenzten Grad im ersten Jahr nach der Pflanzung effektiv, aber versagte in den kommenden 2 Jahren. Daher unterstützen die Ergebnisse dieser Untersuchung nicht die Nutzung von Dünger als eine Methode, die Pflanzenetablierung, Wachstum und/oder Physiologie nach der Verpflanzung in ein städtisches Klima zu unterstützen.

Resumen. Se monitoreó la influencia de la fertilización en el crecimiento de brotes, intercambio foliar de gases, clorofila y contenido mineral en liquidámbar (Liquidambar stryraciflua L.), pa- goda japonés (Styphnolobium japonicum Schott) y fresno europeo (Fraxinus excelsior $\mathrm{L}$.) en un período de tres años después de la plantación en un ambiente urbano. La investigación fue llevada a cabo con árboles recién plantados que estuvieron localizados en sitios urbanos y se fertilizaron después de la plantación. La fertilización fue repetida por dos años después de la plantación y al principio de la primavera. Los resultados mostraron resultados contrastantes de acuerdo a la especie y a los años de las mediciones. La fertilización tuvo un efecto limitado en el primer año después de la plantación pero falló en proveer mejores resultados en los años siguientes. De aquí que los resultados de esta investigación no soportan la utilidad de las aplicaciones de fertilizantes como un método para mejorar el establecimiento de la planta, los mismo que el crecimiento o la fisiología después del trasplante en ambientes urbanos. 